\title{
Trade and Biotechnology in Latin America: Democratization, Contestation and the Politics of Mobilization
}

\author{
PETER NEWELL
}

This research explores the role of agrarian and environmental movements in contesting the development and promotion of agricultural biotechnology through trade liberalization in Latin America. Organized around themes of mobilization, participation and representation, it raises key questions about who mobilizes and how, and about the strategic dilemmas that arise when movements with different histories, membership bases and cultures of protest attempt to work together. Issues of accountability, representation and participation run through the analysis of strategies of organization and claim-making adopted by an eclectic range of groups seeking to contest the role of biotechnology in the structure of agricultural production, the institutions that manage that relationship and the discourses which sustain it. In particular, analysis centres on their responsiveness to the concerns and agendas of poorer groups in the front line of the 'gene revolution' as it plays out in the Latin American countryside, in particular in Argentina and Brazil, the key players in biotechnology in the region.

Keywords: agriculture, biotechnology, GMOs, Latin America

\section{INTRODUCTION}

A range of social movements have mobilized to contest the role of biotechnology in agricultural development in Latin America. The adoption of GM (genetically modified) crops by large global agricultural players in the region such as Brazil and Argentina raises a series of key questions about the industrialization of agriculture (Pengue 2005), issues of access and control of technology and thorny dilemmas about land distribution and its sustainable use. Ties to trade and aid also place the technology at the centre of the political economy of development in the region. Alongside contestation around biotechnology in the Mercosur bloc and the negotiations towards a Free Trade Area of the Americas accord,

Professor Peter Newell, School of Development Studies, University of East Anglia, Norwich, NR4 7TJ and James Martin Fellow, Oxford University Centre for the Environment. e-mail: P.Newell@uea.ac.uk

I am grateful to the three anonymous referees who provided useful comments on an earlier version of this work, as well as the editors of the special issue for helpful suggestions. I would also like to acknowledge the assistance of Rodrigo Luiz in pulling together research materials in Brazil for this work. 
bilateral trade agreements have been used to introduce GM crops into countries that are a centre of origin for crops crucial to the livelihoods of millions of resource-poor farmers (such as potato growers in Peru). Meanwhile countries adopting postures critical of the technology such as Bolivia have found themselves subject to immense political pressure from GM exporters such as the United States on behalf of their agribusiness lobbies.

Against this background of change in the global and regional structure of agricultural production and investment, an interesting mix of civil society organizations and social movements have been evolving repertoires of resistance to the corporate control of agriculture (Jansen and Vellema 2004; Glover and Newell 2004). These have taken the form of battles over the legitimacy, reach and application of intellectual property rights. Fundamental questions of land ownership and distribution have been raised by movements such as Movimento dos Trabalhadores Rurais Sem Terra (MST) and Vía Campesina and the sustainability of land use patterns required by the technology placed in doubt by a wide range of social forces concerned about the social and ecological effects of mono-crop plantations (Peleaz and Schmidt 2004). From a development and rural livelihoods angle, the interface between biotechnology and food security has been a central concern amid calls for food sovereignty, explored elsewhere in the journal in more detail.

Though intimate connections exist between each of these issues and agendas, the focus here will be on contestations by agrarian and environmental groups around the trade-related aspects of biotechnology in Latin America. This implies a focus on transnational biotech-related struggles that seek to contest the promotion of biotechnology in regional and bilateral trade agreements. The foci of these contests are issues of intellectual property rights (IPRs), agricultural liberalization and protection, and biosafety. Given the closed nature of many of these processes, one of the key challenges for movements has been how to democratize policy-making around trade (Newell and Tussie 2006). For some, this has meant working within restricted spaces for institutionalized participation that exist within formal, principally inter-state, decision-making processes. For others, critical of the treatment of agricultural issues within the principal trade agreements in the region, attempts have been made to resist the treaties and to open up trade policy debates to fundamental questions about which commodities and services should be subject (and which should not be subject) to international trade and, critically, who benefits from such policies and who is expected to bear the inevitable costs of adjustment (Newell 2007).

The study is focused on the region's two key players in the biotech sector, Argentina and Brazil, which have had very different experiences of engagement with biotechnology, reflecting contrasting levels of civil society mobilization around the issue, distinct rural political traditions and divergent state strategies towards the technology. It raises key questions about who mobilizes and how, and about the strategic dilemmas that arise when movements with different histories, membership bases and cultures of protest attempt to work together. Issues of accountability, representation and participation run through the analysis

\section{(C) 2008 The Author}

Journal compilation (9) 2008 Blackwell Publishing Ltd

Journal of Agrarian Change, Vol. 8 Nos. 2 and 3, April and July 2008, pp. 345-376. 
of strategies of organization and claim-making adopted by an eclectic range of groups seeking to contest the role of biotechnology in the structure of agricultural production, the institutions that manage that relationship and the discourses which sustain it. In particular, analysis will centre on the responsiveness of those mobilizing to the concerns and agendas of poorer groups in the front line of the 'gene revolution' as it plays out in the Latin American countryside.

It argues that though activists have made important gains, opening up the debate about biotechnology to a plurality of voices, challenging the regulatory structures set up to manage the technology and constructing alternative arenas to debate its risks and benefits, the close alignment of state strategies, which embrace biotechnology as key to their global economic competitiveness, with powerful elements of national and foreign capital severely restricts the space available to contest biotechnology. Moreover, while organized environmental NGOs have made some gains in advancing regulatory reforms and using legal processes to stall the technology's adoption, rural social movements, despite their broader social base and strong international connections, have not been able to shift the debate about biotechnology from one about bio-safety and responsible handling to one about land ownership, property rights and the unequal relations of power which sustain them.

\section{AGRICULTURAL BIOTECHNOLOGY IN LATIN AMERICA}

Despite claims by its advocates that agricultural biotechnology has the potential to boost yields through the use of drought and disease resistant crops for example, reduce pesticide use and address both nutritional deficiencies and hunger (Conway 1999; Lipton 2001), it has generated an unprecedented degree of controversy in Europe and parts of Asia and, as we will see below, in Latin America. Critics have focused on concerns about bio-safety (the potential for loss of biodiversity and contamination of non-GM varieties), impacts upon human health and the level of control the technology affords the companies that provide it over the livelihoods of the rural poor (Warwick 2000; FoEI 2007).

In Latin America, modern agricultural biotechnology was adopted against a backdrop of structural economic reform from the early 1990s. For countries across Latin America, neo-liberal reforms have produced transformations in the structure of agrarian production, concentrations in land ownership and the removal of parastatal support to poorer farmers, all aimed at the intensification of production to meet export markets (Kay 2002; Bellisario 2007; Thrupp 1996; Oya 2005; Murray 2006). The uptake of biotechnology with its packages of seeds, fertilizers and the political technologies of contract farming and monoculture cultivation sat comfortably with the agribusiness-oriented organization of agricultural production in the region's key players. Agribusiness has a leading role in the capital accumulation strategies of the largest countries in the region. Brazil's agribusiness sector still accounts for more than 40 per cent of total GNP. Brazil is the world's third largest exporter of agricultural products and after the United States is the largest soybean (though not the largest GM soy) producer, 
accounting for 7.5 per cent of the country's exports. Moreover, according to the US's own Department of Agriculture, Brazil has sufficient land resources to expand its soybean area and production to challenge the US's leading position (Peleaz and Schmidt 2004). As of 2006, Brazil is the third largest cultivator of GM crops in the world, now cultivating 11.5 million hectares of GM crops. These statistics explain why 'in Brazil, agricultural policy is always high politics' (Paarlberg, 2001, 68). Argentina meanwhile, with 18 million hectares of land under GM cultivation, is now the world's second largest producer and exporter of GM crops, accounting for 23 per cent of global production (James 2006).

What is interesting about Brazil's position, however, is that it also continues to be the primary source for non-biotech soybeans and soybean meal. This explains why Brazil has become such a significant site in the wider social and political struggle over biotechnology, or as Paarlberg puts it 'an important battleground' in the 'global contest over GM crops' (2001, 67). Biotech companies have said of Brazil: 'we are very hopeful that last domino will fall'. ${ }^{1}$ For this reason, environmentalists and rural groups opposed to GM development, according to the same industry spokesperson, have been 'putting up a stink down there in Brazil. They know if that goes, it's all gone'. We will see below how this in fact accurately describes the current situation. This also explains both why companies such as Monsanto have represented the large-scale illegal cultivation of GM crops as evidence of farmer demand for their products whilst sending out a clear message about the futility of claims about keeping Brazil free of GMOs. Even back in 2001, one estimate from the seed industry itself was that of the 2 million hectares planted as soybeans in Rio Grande do Sul, between 400,000 and 750,000 hectares were already transgenic (cited in Paarlberg 2001, 81). Evidence uncovered as part of this research of firms giving out unauthorized seeds at rural fairs to farmers in Paraguay, suggests penetration of markets by default represents an important tool in the arsenal of companies wanting to undermine resistance to the technology and bypass formal decision-making processes.

We will see below how a wave of resistance to the technology dramatically slowed the rate of commercial approvals of GM crops, but how these have once again accelerated more recently in the wake of the approval of the biosafety law in Brazil in 2005 and the resolution, for the time being at least, of the question of which government body has the authority to approve their commercialization. In this sense, activists may have won the battle but lost the war, whereas in Argentina it is possible to argue that activists never even made it to the battlefield.

The take-up of the technology has been uneven across the region. While Brazil has at times been hesitant about adopting the technology as a central agricultural strategy for reasons discussed below, Argentina saw the potential of the technology to boost the countries growth and consolidate for itself a strong position in global markets. Seven GM crop types have been approved for

1 Bob Callanan, spokesman for the American Soybean association, cited in Peleaz and Schmidt (2004, 237). 
commercialization in Argentina, all of them in response to evaluations requested by multinational companies. GM soya is Argentina's most extensive GM crop comprising almost 90 per cent of the 12 million hectares planted in 2001/2002 and nearly half of all Argentina's agricultural production by 2002/3. Underscoring the export-driven nature of this model, in 2003, 98 per cent of soya was exported in Argentina as beans, soy meal for animal feed and soy oil, representing about 20 per cent of Argentina's total exports by 2004 (Galli 2005). This explains Argentina's sensitivity to disruptions in trade flows, as borne out by its participation in a US-led WTO trade case against the EU's de facto moratorium on GM crops.

More importantly, GM exports acquired renewed importance after Argentina defaulted on its US $\$ 140$ billion national debt in December 2001, and an enormous devaluation took place. As an Argentine agriculture trader (chief executive of Cresud) commented: 'the I.M.F. should be very happy with us. Without agribusiness and oil, Argentina would never meet the surplus they are demanding' (Elsztain, cited in Vara 2005, 8). The government decided that income derived from exports would help to increase foreign earnings that would in turn help the poor. Revenues earned from taxes imposed on exports of GM soya, currently 6 per cent of all government revenue, have been used to subsidize the internal market (The Economist 2006). ${ }^{2}$ Other sought effects have been the savings from reduced pesticide use and reduced soil erosion from less intensive tilling. While there is some evidence of these effects, more critical accounts suggest that the record to date has been less positive if a wider range of issues are taken into account, such as evidence of increased chemical imports (such as glyphosate from China), of deforestation associated with land clearing for GM production (Greenpeace 2006a), as well as concentration of land tenure and decreasing employment amongst labourers lower down the agricultural supply chain. Nevertheless, the politics of agbiotech is often referred to as a 'non-issue' in Argentina. With a strong alignment of the interests of state and national and foreign capital about the value of biotechnology, the key contestations are around access and ownership of the technology, rather than around its desirability in social and environmental terms. The percentage of agriculture devoted to biotech and the percentage of exports based on agriculture make it abundantly clear that the material contribution of the biotech sector to the Argentine economy is immense. Indeed, the very nature of the approval system is structured around the export potential of the technology. ${ }^{3}$

2 Such taxes (at different rates) have been in place since 1991, but the claim that government revenue derived from this source is used to combat poverty gained salience in the wake of the financial crisis in 2001/2002.

3 The DNMA (Dirección Nacional de Mercados Agroalimentarios) makes an assessment of the export potential of a crop being considered for commercialization. This was known as the 'mirror policy': not commercializing a crop that had not been already been approved in Argentina's key export markets.

\section{(C) 2008 The Author}

Journal compilation @ 2008 Blackwell Publishing Ltd

Journal of Agrarian Change, Vol. 8 Nos. 2 and 3, April and July 2008, pp. 345-376. 


\section{MOBILIZATION}

Against this background there has been a highly uneven degree of mobilization across the region at the national level and in relation to transnational policymaking arenas. The question of who is mobilizing is a source of dispute among commentators. In general, while environment-oriented urban-based groups have focused their campaigns on issues of biosafety and adopted legal-based strategies to engage with the regulatory regime as currently constituted, rural-based social movements have incorporated biotechnology into their repertoire of campaigning not as a unique technology which may generate new risks, new politics and require new forms of campaigning. Rather, it has been quickly absorbed within existing campaign priorities, ideological frames and modes of collective action.

Along these lines, Scoones, for example, draws a contrast between 'urban centres with significant middle-class populations and a strong NGO presence. They are part of the metropolitan, relatively elite circuits where the higher profile activist networks are centred' and 'the deprived rural hinterlands where a different activist discourse may be present' $(2005,3)$. For Peleaz and Schmidt, on the contrary, 'it would be wrong to conclude, from the lawsuits brought by IDEC (Instituto Brasileiro de Defesa do Consumidor) and Greenpeace, that resistance to GMOs in Brazil is recent and mainly fomented by urban organizations of consumers and environmentalists'. Instead, they argue, 'this resistance is a direct outcome of a movement that challenged the Green Revolution model of agricultural modernization at the end of the 1970s' (2004, 239). It was this latter emphasis that gave rise to claims of farmers' rights and autonomy in relation to the production of seeds and consequent efforts to resist the extension of property rights over genetic material to corporations. In practice, it is probable that groups present different parts of the campaign to different audiences depending on their perceived receptivity to that element of the concern. For example, issues of labelling and bans play well with an anxious urban middle class, while socio-economic, livelihood and trade concerns resonate more powerfully for marginalized rural groups who are more directly affected by these. It is clearly also the case that some discourses and modes of engagement are required for influencing state, as opposed to corporate actors, for example. This also reflects ideological choices about whether campaign goals are achievable through engagement with government in formal institutional arenas, as opposed to maintaining oppositional stances through mass actions.

These distinct repertoires of protest can be observed in the way many ENGOs (Environmental NGOs) engage in the economics of the issue and in the technical debate about crop biosafety. They, to some extent, accept the debate on terms bounded by regulatory discourse and parameters. As Scoones notes, the danger here is that the types of science deployed and the nature of the argument used are in essence responses to and so framed by the pro-GM position' $(2005,39)$. The emphasis for many is upon improved mechanisms of oversight and control, drawing on the expertise they bring to bear and the concerns of their membership. This is in contrast to movements that seek to challenge the

\section{(C) 2008 The Author}

Journal compilation @ 2008 Blackwell Publishing Ltd

Journal of Agrarian Change, Vol. 8 Nos. 2 and 3, April and July 2008, pp. 345-376. 
very structure of production and ownership which creates biotechnology. Even within the state the targets are distinct. While ENGO lobbying tends to centre around Environment ministries with responsibility for biosafety measures, Ministries of Agriculture and Economy are often the targets of rural movements, those with responsibility for making and implementing policies that impact their livelihoods most directly. Nevertheless, when it comes to formulating trade policy, agrarian and environmental groups rarely have strong ties with the ministries of trade and finance that lead policy deliberations, a distance from policy influence which is exacerbated within regional institutions such as Mercosur, which continue to function on a strongly inter-governmental basis.

Despite these distinct backgrounds and strategies, increasing links between urban NGOs and rural social movements have served the needs of each. Though resistance to GMOs has traditionally come from urban-based environmental and consumer groups, the main peasants associations, such as the landless movement (MST) and the National Confederation of Agriculture Workers (CONTAG) in Brazil, have also stated their opposition to GMOs. The CONTAG, for instance, in its 2002 Agenda, campaigned against the production and commercialization of GMOs, and for the labelling of GMOs that have been commercialized. Links to other groups have served both rural movements and the NGOs they align themselves with. Peleaz and Schmidt note: 'the emergence of . . movements aiming at the reinforcement of small farmers' autonomy improved the bargaining power of social organizations in the rural sector and provided the necessary legitimization for NGOs to represent the political interests of the rural sector in congressional disputes' (2004, 242).

Vía Campesina was critical in bringing the MST into the struggle against GM agriculture, broadening the social base of the struggle and in so doing lending it greater perceived legitimacy. Having on board groups who represent smaller producers, leaving aside the questions about how effectively they do this, lends moral and political credibility to coalitions claiming to act on behalf of and defending the interests of smaller producers in the face of multinational biotechnology companies. Likewise, for the NGOs making up the campaign for a 'GMfree Brazil', a link to the MST provided the means to greatly strengthen their credibility:

For the small group of NGOs, which to that point were the core network members, this was critical. They could no longer be criticized for just being unrepresentative, unaccountable, foreign-funded NGOs (which they were), but were linked to a mass movement with official and informal connections to the PT, allowing political clout well beyond what was possible before. (Scoones 2005, 22)

Some coalitions are more NGO-dominated, nevertheless. 'Brazil Free of GMOs', for example, is an NGO coalition made up by Greenpeace, the Institute for the Defence of Consumers (IDEC), Services and Advice to Alternative Agriculture Projects (ASPTA), ActionAid Brazil, Social Assistance and Education Federation (FASE), the Socio-Economic Studies Institute (INESC) and the 


\section{Peter Newell}

Advisory and Research Centre (ESPLAR). Their main purpose is to promote public awareness concerning the environmental and health risks of the production and consumption of GMOs. There has, nevertheless, been enough common ground between NGOs and movements to articulate a common critique of the trade in GM products. Mobilizations around the production and trade in the products of agricultural biotechnology are anchored around a series of key mobilizing claims which in turn draw on broader critiques of prevailing models of agribusiness production and trade. There are differences among groups regarding the degree to which they would support all of these claims. Few, if any, would subscribe to all elements and certainly not all of them equally. What follows, therefore, are recurrent themes common in the discourse and claimmaking of activists.

1. A key over-arching theme is the excessive, unchecked power of agri-business manifested most obviously in the concentration of land ownership and control of the market. In Brazil alone, for example, Monsanto is the largest foreign seed company, controlling 60 per cent of the national market of maize and 18 per cent of soybeans. ${ }^{4}$ Monsanto purchased five different national seed companies in Brazil, including some of Brazil's best established seed companies such as Agroceres. In one year, Brazil's previously domestic hybrid seed industry became 82 per cent owned by Monsanto (Paarlberg 2001, 70). The agribusiness model is accused of concentrating wealth rather than distributing it, with one figure put forward by MST leader João Pedro Stedile suggesting that just ten multinational companies operating in Brazil receive more credit than four million smaller family farms (Stedile 2004). Trade liberalization is seen to have enabled and accelerated this concentration. Echoing what was said above about the suitability of existing systems of agricultural production for the cultivation of GM, activists in Brazil claim that the latifundium is a powerful ally of the biotech multinationals (Andrioli 2006). Specifically, there is an alleged link between latifundium, agribusiness and transnational firms such as Cargill, Monsanto, ADM and Bunge, seen as the "main enemy of the MST' (Santos 2006).

2. Drawing strongly on dependency critiques which highlight the dangers of over-reliance on private capital for the development of countries on the periphery of the global economy, activist discourses invoke themes of autonomy and sovereignty around food. For MST and Vía Campesina, 'food sovereignty' has emerged as a central theme in campaigning against agri-business in general and its role in biotechnology development in particular, generally taken to mean 'producing, exchanging and consuming food in and closely around one's territory'. Vía Campesina claims, for example, 'a nation will only be sovereign if it can control the production of its own seeds' (Vía Campesina n.d. b). This element is strongly related to trade: dumping, cheap

4 It is alleged that in terms of GM seeds specifically, Monsanto is responsible for 88 per cent of a market (Igor Felipe de Santos, MST 'Multinationals seek to dominate the entire food chain', see Vía Campesina web site, http://www.viacampesina.org/main_sp). 
seeds and the removal of quantitative restrictions on agricultural imports. Indeed, Vía Campesina issued an open letter to Brazil's President Lula arguing that the WTO has no role in regulating access to fundamental rights such as food and calling instead for a suite of measures aimed at promoting food sovereignty and genetic diversity (Vía Campesina n.d. a).

3. Beyond generic issues of sovereignty and autonomy, a specific set of concerns with access and control of technology and knowledge feature prominently in activist discourses. IPRs, a key instrument of trade policy in regional and bilateral trade agreements, have attracted particular fire. In Brazil there was significant mobilization around the Patent Bill proposed by President Fernando Collor, focused on the issue of patenting seeds. This included a mix of 'agro-ecology and environmental NGOs, as well as the Catholic Bishops Conference' (Peleaz and Schmidt 2004, 242). A campaign around the call of 'No patents on life' meanwhile brought together a Forum on the Free Use of Knowledge (Forum pela Liberdade do Uso do Conhecimento). This umbrella organization included over a thousand civil society organizations including trade unions, professional organizations, churches, scientific societies, NGOs and even elements of national capital benefiting from looser protection of intellectual property such as pharmaceutical companies. Bilateral trade agreements have also been a vehicle for strengthening the protection of intellectual property rights and hence become a focal point for activist campaigning. For example, Peru's negotiation of a free trade agreement with the US included provisions to synchronize the country's levels of IPR protection. Activists have claimed that this will have a profoundly negative affect on peasant farmers cultivating seeds and crops that will now be subject to patent control (Third World Network 2006).

4. The campaign 'Terminate terminator' in Brazil was also centred around opposition to the use of GURTs (Genetic Use Restriction Technologies) in seeds which require farmers to buy new seeds each season rather than re-plant and exchange them with other farmers. The claims focused on the likely effect of such a technology in Brazil, where it is estimated that as many as 87 per cent of all farmers do not buy their seed (Radio Mundo Real, n.d.). On 22 March 2006, a day of action against terminator technology was declared in which, for example, 300 rural workers demonstrated in Curitiba against the suspension of the moratorium preventing the cultivation of terminator seeds (Santos n.d.). The decision of the 8th meeting of the Conference of the Parties of the Convention on Biological Diversity (CBD) held in Curitiba, Paraná to uphold the moratorium on the use of terminator seeds was used by Vía Campesina to lend credibility and support to this campaign (Vía Campesina n.d. c).

The trade in food aid has also drawn attention to the question of control over food amid claims about the double-standards employed by large biotech firms that use the developing world as a dumping ground for technologies rejected elsewhere. Clapp (2006) shows how GM food aid has been used to undermine resistance to the technology. Ecuador was the first known 
developing country to receive food aid containing GMOs in a shipment of soy from the US and channelled through the World Food Programme. It was eventually destroyed following complaints by Ecuador. When food aid maize was sent to Bolivia in 2002, in spite of the country's moratorium on the import of GM crops, the issue of double-standards once again came to the fore. The GMOs in the Bolivian aid contained StarLink corn in a modified form not approved in the US for human consumption (only as animal feed). NGOs claimed that despite the fact that when the StarLink was found in the US food supply it was immediately removed from the market, the US made no such effort to remove the maize from Bolivia, prompting accusations of double-standards (Clapp 2006). The use of food aid within Argentina at the time of the country's food crisis also generated a counter-discourse around the corporate response to the crisis that GM was being used as 'forrajeros para los pobres' (fodder for the poor) or worse still as an opportunity to access more potential consumers for GM products (Kossoy 2003).

5. The potential environmental impacts of biotechnology have been another key element in activists' critique of biotechnology. The cross-border trade in genetically-modified seeds is notoriously difficult to monitor and regulate and has hence heightened concerns about biosafety and the potential for crosscontamination of non-GM crops, such as occurred with GM maize in Mexico (Fitting 2006). Other mobilizing claims centre on the deforestation of land to make way for monoculture GM crop cultivation. In Argentina, for example, groups such as Grupo Reflexión Rural and Greenpeace have protested the environmental consequences of the mono-cultivation of soya, including loss of soil fertility and deforestation in particular (Benbrook 2005). ${ }^{5}$ Because of the extent of mono-crop cultivation of soya, they refer to Argentina as the 'Republica Unida de la Soja' (Boy 2006). The clearing of forests to make way for soya plantations in Argentina has served to globalize this campaign, which may follow the route of neighbouring Brazil in finding itself the focus of a transnational campaign. In Brazil, the clearing of Amazonian rainforest for soya cultivation has prompted environmental protests and attempts to elicit from leading firms promises not to buy illegally cultivated soya. In a full-page advertisement in The Guardian, Greenpeace described as 'A turning point in the fight to protect the Amazon' the pledge by food manufacturers and fast-food chains such as McDonalds not to use soya illegally grown in Brazil. The commodity MNCs Cargill, ADM and Bunge are named as those responsible for financing the forest destruction as a result of the soya farming (Greenpeace 2006b).

Some groups within Latin America have objected to the development of GM trees. ETC (Action Group about Erosion, Technology and Concentration) ${ }^{6}$

5 Critics of this position, including some environmentalists, suggest that biotechnology per se is not the main driver of mono-cultivation as some activist campaigns claim. Interview, ENGO activist, 9 November 2006.

6 Formerly RAFI (Rural Advancement Foundation International) based in Canada.

\section{(C) 2008 The Author}

Journal compilation @ 2008 Blackwell Publishing Ltd

Journal of Agrarian Change, Vol. 8 Nos. 2 and 3, April and July 2008, pp. 345-376. 
Mexico has expressed concerns about the reach of the pollen GM trees can produce. The World Rainforest Movement (WRM) also mobilized around calls for a ban on the release of GM trees in support of a precautionary stance taken by CBD negotiators, an issue raised at COP8 (WRM 2006). Groups such as Rede Alerta contra o Deserto Verde meanwhile focus on the social and ecological consequences of mono-crop or tree plantations, particularly expulsions from land and the effects on indigenous Indians (RACDV n.d.).

Each of these discourses resonates with broader global debates and contestations around farmers' rights, food sovereignty, biodiversity protection and critiques developed by the anti-globalization movement. It is this broader framing of biotechnology's relationship to trade that connects anti-GM campaigns with the agenda of campesino groups. During negotiations towards the FTAA there have been explicit inter-governmental statements in support of the trade in genetically modified organisms, prompting concerns among activists that FTAA will provide a back door route to spreading the use of GMOs in the region (Global Exchange 2004). This would be against the expressed reservations of countries like Bolivia about the technology, and driven by the need for the US, Canada and Argentina, in particular, to find new markets for products rejected in Europe and parts of Asia. This issue has been raised by campesino groups in countries that serve as a centre of origin for key crops such as maize, like Mexico, a country which has already experienced contamination of non-GM crops by transgenic varieties. $^{7}$ This has fed into a concern that proposed IPR provisions within the FTAA might continentalize North American patenting provisions, over-riding communal and indigenous peoples' rights (Acción Ecológica 2004).

\section{Transnational Organizing}

It is around these claims, and their links to broader concerns about the model of market integration for the region with which they are associated, that joint campaigning between transnational biotech activists has been possible. This section of the study, therefore, reviews and assesses the strategies adopted by activists in Latin America to contest biotechnology and its promotion through trade agreements in the region. It is difficult, nevertheless, to assess with any degree of accuracy the true extent of transnational mobilization per se as it pertains to the relationship between biotechnology and trade in Latin America. Transnational coalitions with a broad membership base often operate in a very loose, decentralized fashion, with the head of the organization functioning mainly as a coordination unit and public face of a coalition whose transnationality mainly derives from the fact that it has members in many different countries that subscribe to the basic position of the organization. For example, Vía Campesina has a very small staff consisting of an executive secretary and a handful of support staff relying heavily on yahoo list serves to distribute position papers and issue

7 Meeting with Grupo de Estudios Ambientales, Mexico City, August 2002.

\section{(C) 2008 The Author}

Journal compilation (C) 2008 Blackwell Publishing Ltd

Journal of Agrarian Change, Vol. 8 Nos. 2 and 3, April and July 2008, pp. 345-376. 
announcements (Edelman 2003; Borras 2004). Similarly, the HSA (Hemispheric Social Alliance), through bringing together a broad range of movements around opposition to the FTAA, exists on an incredibly small staff and budget. The outward appearance of mega-coalitions of transnationally organized activities often betrays the reality of small but tightly organized offices with exceptionally good global connections. Moreover, the ties that sustain networks such as this are more often than not personal relationships rather than formal or regular inter-organizational collaborations (Edelman 2003).

We have seen above how coalitions of environmentalists and peasant-based movements have adopted strident positions on the issue. Below I raise questions about the extent to which those concerns derive from their membership base or rather from strategic and opportune positioning in relation to a current focus for mobilizations. Here I briefly address the 'dynamics of inter-connectivity' alluded to in the Introduction, across levels from local to global via the regional and back again. As with the analysis above, such forms of organizing raise issues of representation and accountability in equal measure.

There is evidence both of generic anti-biotech coalitions within the region as well as alliances aimed at dealing with specific aspects of it. For example, the Red por una América Latina Libre de Transgénicos (RALLT) was formed in January 1999 at a workshop in Quito on the theme of GMOs and biosafety. The initial impetus came from 'the need for communities to develop global strategies against the introduction of transgenic organisms and to prevent their introduction into the region' (RALLT 2007; translated). The network states among its aims: the protection of local communities and national processes which seek to avoid the introduction of GMOs; the protection of governments' autonomy in deciding whether to accept GM agriculture and ensuring that civil society and affected groups are included in this decision-making; and, finally, to work towards a moratorium on the release and trade in GMOs until such a time as there is complete evidence of their safety and societies have had a chance to debate in a informed way the risks and impacts associated with the technology. Its membership is broad and includes campesino organizations, indigenous groups and environmentalists. Any group or individual that agrees with the declaration developed by the group on GMOs can be a member of the network. Alongside such broad coalitions whose position is against the technology in general, other coalitions target specific uses of it. The Red Latinoamericana contra los Monocultivos de Arboles is against the use of GM trees on grounds of the environmental damage they cause, noted above, and the Forum for Biological and Cultural Diversity was formed in 2001 in Chiapas, Mexico to 'defend native medicinal and crop plant varieties against threats posed by free trade'. ${ }^{8}$

Many such coalitions have a similar starting point to groups such as ETC (Action Group on Erosion, Technology and Concentration) but with strong international connections. ETI's focus has been on issues of IPRs and GURTs or

8 For more details on the forum see http://www.laneta.apc.org/biodiversidad/.

(C) 2008 The Author

Journal compilation @ 2008 Blackwell Publishing Ltd

Journal of Agrarian Change, Vol. 8 Nos. 2 and 3, April and July 2008, pp. 345-376. 
'terminator' technology. They have had a consistent presence at international meetings on biosafety, organizing workshops and side-events, lobbying governments and sharing research and position papers. An organization playing a similar role within Latin America is the Red Interamericana de Agriculturas $y$ Democracia (RIAD) which operates as an information clearing house and source of analysis for NGOs and peasant organizations. ${ }^{9}$

Some pre-existing regional and international bodies working on rural issues and seeking to protect the interests of campesinos have adopted positions on the issue of biotechnology. For example, the Coordinadora Latinamericana de Organizaciones del Campo (CLOC), formed in 1994, brought together representatives from 84 organizations from 21 countries working on a common agenda of agrarian reform, food sovereignty and indigenous rights. Given this, it is closely aligned with Vía Campesina, and the overlap between their members is extensive. Almost all Vía Campesina member organizations in Latin America participate in CLOC and many CLOC organizations participate in Vía Campesina (Edelman 2003). As well as supporting one another's networks, both coalitions have, in turn, played instrumental roles in constructing other coalitions on specific issues such as the Forum for Biological and Cultural Diversity mentioned above or the IPC (International Planning Committee for Food Sovereignty). This is a global alliance of dozens of transnational agrarian movements plus other civil society groups, involving about 500 organizations across the world.

There are clearly many biotech activists whose concerns are specific to the technology or particular aspects of it, whose critique is not underpinned by a broader preoccupation with resisting neo-liberalism. For anti-globalization activists on the other hand, with whom Vía Campesina is most closely aligned, biotech is one more symptom of an economic system which benefits agribusiness at the expense of smallholders. There has been a convergence of diverse and competing agendas around a common critique of neo-liberalism. Edelman notes: 'trade, phytosanitary measures, intellectual property rights, animal and human health, environment, human rights, biotechnology, gender equity and food sovereignty have, in everyday political contention, become inextricably bound up with one another' $(2003,212)$. This is true both of groups such as Vía Campesina as well as coalitions set up to contest particular trade accords such as HSA, whose alternative agreement for the region 'Alternativas para las Américas: Hacia la construcción de un acuerdo hemisférico de los pueblos' reflects the diversity and interplay of these issues.

The intimate connection between biotech's development in Latin America and the evolution of trade agreements aimed at securing market access for the technology has placed agricultural biotechnology firmly on the radar screen of opponents of market-driven regional integration. For example, opposition to

\footnotetext{
9 APM-Mondial played an important part in creating this network providing another illustration of the way in which existing networks tend to spawn new networks.
}

\section{(C) 2008 The Author}

Journal compilation @ 2008 Blackwell Publishing Ltd

Journal of Agrarian Change, Vol. 8 Nos. 2 and 3, April and July 2008, pp. 345-376. 
FTAA is re-framed as a broader struggle against the global industrialization and intensification of agriculture. Connections have been forged to international campaigns against GMOs, which also have a regional resonance given the centrality of Argentina and Brazil to the global GM debate. According to Teubal and Rodriguez, 'various campesino movements have successfully articulated in recent years an authentic global movement' (2002, 197). This is grounded in opposition to TNC control of agriculture (including patenting and biopiracy), free trade in agricultural produce (especially dumping), the use of hormones and transgenics and in favour of food security and food sovereignty. Coalition-building of this sort and a range of protest activities have been the main strategies adopted by campesino movements, often aided by the financial support of sympathetic groups in Europe and North America, funding the travel of campesino groups to major anti-FTAA demonstrations (Newell and Tussie 2006).

As a result of this coalition-building, it is possible to argue, as Edelman, does that 'participants in the peasant and farmer networks have also come to have a dynamic sense of themselves as political actors, empowered with new knowledge, conceptions of solidarity and tools of struggle' (2003, 214). Coalitionbuilding has also taken place horizontally between movements. In Brazil, though the campaign for a GM-free Brazil has formed the epicentre of protest, links have evolved between peasant-based movements such as MST and Vía Campesina and a range of environmental and consumer-based groups including Greenpeace and ESPLAR, Centro de Pesquisa e Assessoria, development groups such as ActionAid and AS-PTA (Assessoria e Servicios a Projetos em Agricultura Alternativa), education groups such as FASE (see below) and INESC (Instituto de Estudios Socio-Economicos). Critically important links were also forged with the PT (Workers' Party). Symbolically important relations were also built with the Church through the Basic Ecclesial Communities (Boff n.d.). The Pastoral Commission of Land produced a declaration on GMOs, for example, listing a series of social and environmental objections to the use of the technology (PCL 2004), as well involving itself in a campaign to 'save creole seeds' by creating community seed banks in the face of intellectual property claims by multinational companies (PCL n.d.). Amid such diversity it was possible nevertheless for each group to pursue its preferred strategies of protest and use its resources where the returns are likely to be highest. Scoones notes: 'each was able to focus on different areas of advocacy and action - some more direct and protest oriented; some more focused on practical demonstration of alternatives; some through courts and the media' $(2005,12)$.

One strategy activists have adopted is to disrupt the actual trade in GM produce through legal and direct means. In 1997 Greenpeace went to court to prevent two container boats carrying GM maize from Argentina bound for Brazil and its poultry industry, in particular, from setting sail. The move was successful in prompting public debate as boats full of Argentine corn arrived but were turned away and held offshore while a decision was made about whether to allow the GM commodities into the country. MST also intervened 
physically to stop the import of GM produce into Brazil when in July 2000 an MST-led group of farmers attacked a ship in Recife containing GM maize imported from Argentina (Scoones 2005). A legal action was also brought against the Ministry of Justice in an effort to block further shipments of soybeans from the US on the basis that no labelling provisions yet existed in Brazil to protect consumers. The controversy led to mandatory testing of imports for GM content and, according to Paarlberg (2001, 84), significant GM imports from the US and Argentina were avoided to minimize controversy. Though, in the short term, such actions did serve to draw attention to a poorly regulated trade and its associated risks, forcing the issue into public arenas and soliciting a response from the government, attempts to stall such an economically lucrative trade have been rendered futile by the shifts in the Lula government's position towards biotech. On 22 March 2005, for example, CTNBio approved the importation of 370,000 tonnes of GM corn from Argentina to be used as chicken feed.

It is often through working alongside media-savvy transnational actors that national struggles receive international attention, potentially acting as a lever for change. The problem for groups such as MST is that the more quotidian struggles of rural movements, particularly where the same strategy is used repeatedly (the land invasion), are less newsworthy. The radical content of the politics behind the action and the fact that such actions often take place in remote rural settings makes it more likely that they will be beyond the radar of national journalists based in urban centres. The lack of novelty of the land invasion for media seeking a new angle, and rarely sympathetic to the movement's goals, makes it hard to publicize key actions in mainstream media (Andrioli 2006). By contrast, the presence of 'international anti-GM stars' (Scoones 2005, 15) at World Social Forum (WSF) meetings in Brazil, who in many ways serve as the 'organic intellectuals' of the anti-GM movement lending it visibility, weight and direction (in different proportions), has helped to garner media attention, useful to national struggles against biotech. Media interest for example was ignited by the involvement of renowned anti-GM activist and farmer José Bové, who was arrested for participating in an MST-led invasion of a Monsanto farm in Rio Grande, destroying five acres of GM crops (Scoones 2005). Other celebrities include Vandana Shiva, the Indian writer and activist, and Canadian farmer Percy Schmeiser, who was involved in a court battle with Monsanto, also claimed he was using their seed illegally against his claim that his crops had been 'contaminated' by GM crop trials in neighbouring fields (Glover and Newell 2004). Involvement in the WSF proved effective for domestic movements in centring attention on this issue and building coalitions with international activists. Such fora also provide an opportunity to draw attention to groups' own agendas such that the WSF in 2001 became the venue for a 'World Forum on Food Sovereignty' supported by CLOC and Vía Campesina among others. Indeed as Edelman suggests, 'high-profile participation in international protests and civil society gatherings continues to be hallmark of Via Campesina activity' (2003, 206).

\section{(C) 2008 The Author}

Journal compilation () 2008 Blackwell Publishing Ltd

Journal of Agrarian Change, Vol. 8 Nos. 2 and 3, April and July 2008, pp. 345-376. 
It is important to recall, nevertheless, that even seemingly transnational mobilizations often derive their energy and strategy orientations from particular national settings. Brazil has served this role as an epicentre in the broader social struggle over biotechnology. Particular sites in the global contest over the future of agricultural biotechnology become transnationalized because of the symbolic value they generate and the claims projected onto them by activists elsewhere. The romanticism that surrounds Latin American social movements in general is certainly evidence in relation to the MST, particularly among Western-based antibiotech activists keen to deflect claims that their rejection of the technology is elitist and serves to deny poorer farmers access to a potentially welfare-enhancing technology.

As we have seen within Latin America and in other arenas of global economic policy, most notably the WTO, efforts to shape regional and transnational processes are also channelled through the state. Much effort is still geared towards shifting or sustaining the positions of national governments as a way of shaping international policy. Hence, while there may be evidence of what Tarrow (2005) calls the 'new transnational activism' responding to and scaling up to political opportunity structures available within international and regional fora, the majority of biotech-related activism continues to take place at the national level, even if it is linked to groups elsewhere and is also often pitted in opposition to transnational actors operating in domestic arenas (such as biotech TNCs). For most activists, the primary target remains the state and the primary audience a national one, even if international levers can be used to generate domestic reform. This is particularly understandable for those rural movements that have engaged with the issue such as MST, where biotech is viewed as another manifestation of an unjust division of land and wealth from agricultural production, which the state has the overriding responsibility to address. These are issues beyond the jurisdiction of regional and international bodies even if decisions they make, especially around trade, have profound national and local impacts.

National campaigns within the region may well be managed through bodies serving as coordination points and with a transnational base of representation. They serve to direct their claims towards regional and global arenas, such as the WTO or multilateral arenas dealing with issues which impact upon rural livelihoods, such as the CBD's deliberations about access and benefit sharing or the debates about restrictions on the use of GURT technologies. Activists make use of their ability to operate simultaneously in different political spaces and to transgress scales. This involves, for example, mobilizing nationally within 'transnational arenas' such as the negotiations of the Cartagena Protocol. With access to transnational audiences such arenas serve as platforms to advance national political objectives. For example, around 1,500 peasants organized by Vía Campesina demonstrated in Curitibia, where the MOP3 (Meeting of the Parties) was being held. They were protesting the length of time allowed before requirements regarding the identification of transgenics in food come into play, which is currently four years.

Despite the claims that global social movements are more than the sum of their parts or that, rather like claims made of globalization itself, they render

\section{(C) 2008 The Author}

Journal compilation () 2008 Blackwell Publishing Ltd

Journal of Agrarian Change, Vol. 8 Nos. 2 and 3, April and July 2008, pp. 345-376. 
boundaries irrelevant, collapsing, transgressing and merging spaces of activism, there is a need for caution about the extent to which activism is truly borderless. The case of activism around trade and biotechnology in Latin America would seem to lend weight to Tarrow's (2005) claim that much activism that is called transnational is often actually the global expression of demands articulated in a particular national setting and intended to shift the position of a specific nation state. What we seem to observe are the emergence of 'focal points', moments or spaces of political convergence in which diverse national priorities, campaigning emphases and strategic preferences can be expressed. These can take the form of a 'discourse coalition' (Hajer 1995) or serve as a narrative that unites eclectic movements across different territories, a malleable story-line or device that works in different settings and therefore allows for the political buy-in of groups that might not otherwise work together. The concept of 'food sovereignty' certainly works in this way with a generic ability to serve diverse (and sometimes conflicting) campaign needs simultaneously. Hence while for MST this provides a starting point for claims about land redistribution, for other rural groups it is a rallying cry for the defence of local economies while, at the same time, allowing many green groups to argue for ecologically sustainable (non-GM) food production.

What we may find more evidence of is high levels of transnational coordination within international NGOs such as Greenpeace. Groups such as this can play a bridging role between campaigns in different global sites, emulating tactics adopted by their groups in one part of the world in other locales. For example, there has been a strong tradition of using direct action in Europe by Greenpeace, GenetiX snowball and other groups uprooting GM crops in field trial sites. Such strategies have been adopted in Brazil too, where there have been invasions of Monsanto and other research stations and the uprooting of trial crops by Greenpeace and other activists. In January 2001, as part of a broader anti-globalization protest, more than 1,000 workers from the MST invaded a Monsanto plant in Rio Grande do Sul and said they would stay there indefinitely to protest against GM crops being developed by the company. It seems likely that we will see heightened emphasis on strategies of direct action in the face of government moves to further open the market to GM development. For example, in March 2006 Vía Campesina occupied a field trial site of the biotech firm Syngenta to denounce the 'illegal' use of GM soy and maize in the area. In November 2006 state governor Roberto Requião signed a decree of intent to expropriate the Syngenta farm. According to Kenfield and Burbach (2007), 'the decree was a huge political victory for the rural and environmental movements, challenging the power of agribusiness in Brazil'. If it was, it was short lived. In July 2007 Syngenta and its allies succeeded in overturning the decree and Vía Campesina was evicted from the site. More recently (October 2007) such occupations have resulted in violence and even the death of a Vía Campesina activist in Paraná following an occupation by 150 members of the group (Vía Campesina 2007; Kenfield and Burbach 2007). This is certainly transnational activism around biotech, albeit within one organization with significant sharing of information and resources aimed at aligning national struggles with international campaign priorities. 


\section{Peter Newell}

In terms of peasant-based transnational movements per se, activism around biotechnology in Latin America can be located as part of the trend Edelman (2003) describes of a 'globalization from below', in which agriculturalists develop common agendas and protest repertoires on issues as diverse as trade and human rights issues. As a result he suggests 'farmers have achieved a prominence in international arenas that they rarely enjoyed in their own countries' (2003, 185). Despite the differences of material interests that exist between them, what unites poorer farmers and landless labourers is a common experience of exploitation, which can be described in class terms which transgress national borders. Hence although those involved in rural social movements invoke multiple identities such as ethnicity and gender in asserting their rights and explaining their exclusion, exploitation, not consciousness or common awareness are the hallmarks of class (Burnham 2002, 117), such that mobilizations around biotech can be usefully understood in class terms. De Ste. Croix claims that "class (essentially a relationship) is the collective social expression of the fact of exploitation, the way in which exploitation is embodied in a social structure' (1981, 43, cited in Burham 2002, 117). The issue in this context cannot be reduced merely to control of the means of production, since many smaller farmers do have land titles, unlike the landless labourers they employ. Rather, the resistance that results from exploitation by larger commercial interests and the state creates a political tie between an affected class of farmers across Latin America and beyond.

For example, the prospect of a trade agreement with far-reaching effects on rural economies serves to galvanize social action and provides a common threat for smaller producers. This was certainly the case with the NAFTA agreement that spawned a whole series of coalition-building amongst the probable losers of an integrated market and latterly the FTAA (Teubal and Rodríguez 2004). RMALC (Mexican Network Against Free Trade) was one manifestation of this, serving as an important source of analysis on trade policy for peasant movements (Edelman 2003; Icaza 2004). Issue-specific groups such as En Defensa del Maíz (EDM 2002), focused around free trade and GM corn, and national coalitions of campesinos such as El Campo No Aguanta Más, ${ }^{10}$ drawing attention to the negative impacts of NAFTA upon the livelihoods of the rural poor, also sprung up in the wake of the agreement. Trade politics connect macro economic re-structuring with local livelihood concerns 'blurring' domestic and foreign policy in new ways. There is also a sense with activism around trade issues that nationality ceases to be the primary point of reference even if lobbying continues to be channelled through the state. Expressions of solidarity, encouraged through joint demonstrations, declarations, exposure tours and the like lend weight to Edelman's claim that trade policy 'increasingly divided people less along national lines than in relation to shared class, issue-based or sectoral interests' $(2003,198)$. With indigenous and campesino groups, identity politics which transgress state

10 Translated as: 'The Countryside Cannot Take Any More'. For an example, see http:// www.grupochorlavi.org/php/doc/documentos/elcamponoaguanta.pdf. 
borders are certainly also key. The prospect of the FTAA served to stretch these ties across an entire continent embodied in the creation of the Hemispheric Social Alliance.

\section{PARTICIPATION}

Though many of the mobilizations described above seek to contest the relationship between biotechnology and trade through 'outsider' strategies of protest and resistance, some groups have sought to make use of available channels of institutional participation or 'invited spaces' made available to them by national governments and regional trade institutions dealing with the issue of biotechnology.

There is not space here to review the full array of spaces available to organized civil society inside the formal arenas of trade policy in Latin America associated with agreements such as NAFTA, FTAA, Mercosur, and in any case these have been reviewed elsewhere (Newell and Tussie 2006). It suffices to note that the participation of civil society actors has been aimed at generating public and political support for controversial trade agreements rather than opening them up to serious public scrutiny. Openings for activists to make their views heard have been further circumscribed by the overwhelming degree of support leant to the technology by leading players in the region such as Brazil and Argentina. Within the institutions of Mercosur, such as the SGT6 ${ }^{11}$ Working Group on the environment, despite early framings regarding the potential risks associated with the technology, Argentina played a lead role in vetoing the biosafety clause of a proposed draft. The Framework Agreement accepted in 2001 has no section at all on biosafety issues (Hochstetler 2003). When Argentina called a meeting of Ministers of Agriculture in Mercosur in 2005 to generate support for its position against paying Monsanto royalties on soya crops (rather than seeds), initial support was forthcoming from Brazil and Paraguay. Intense pressure in the wake of the meeting, however, led to these governments retracting their positions on the basis that they were concluding their own agreements between the private sector and Monsanto. ${ }^{12}$

Beyond the regional trade politics of biotech in Latin America, many governments in the region are also signatories to the Cartagena Protocol on Biosafety, which in turn requires countries to create mechanisms for public participation and consultation around the design of their National Biosafety Frameworks (Glover et al. 2003). At national level, therefore, this had led to the establishment of national invited spaces of participation around biotechnology. Democratizing policy in this area has been extremely difficult, nevertheless. In Brazil, briefs of the CTNBIO meetings agendas are placed on their website before the meetings and decisions taken are officially communicated to local and regional authorities and to other federal institutions such as the Ministry of the Environment and Ministry of Health. The decisions are also posted on the Internet after each

11 Sub-Grupo de Trabajo.

12 Interview at Ministry of Agriculture, Argentina, November 2007.

\section{(C) 2008 The Author}

Journal compilation @ 2008 Blackwell Publishing Ltd

Journal of Agrarian Change, Vol. 8 Nos. 2 and 3, April and July 2008, pp. 345-376. 
meeting. However, the meetings are held behind closed doors and the public cannot access the complete reports of the discussions. The government justifies this approach through reference to commercial confidentiality requirements. The requirements for experimental plantations are published in the official government journal and on the Internet one month in advance in order to allow every interested citizen to declare their position as part of this provision. However, despite increased access to information, the Council has received very few contributions from the public to date. The CTNBIO has supported events promoted by the Biosafety National Association (ANBIO), such as the first Brazilian Congress on Biosafety, on September 1999. Activists complain, however, that a body that is meant to operate as the regulatory organ on public health and environmental issues should have maintained its independence from the companies represented by ANBIO. The event received sponsorship from biotechnology companies including Monsanto, Novartis, Agrevo and Du Pont. As a result, according Pelaez and Schmidt (2004, 249-50) CTNBio faced a serious crisis of credibility in Brazilian society who suspected it was stimulating biotechnology to benefit the multinationals.

The conflictual and legal nature of the policy debate, described by Scoones in this journal, is seen by some as a result of grievances by groups that felt they were not consulted and continue to be left out of policy-making processes on these issues. In this regard it is worth citing a report of the Brazilian MP Ronaldo Vasconcellos, concerning CTNBIO's activities:

We believe it desirable that the CTNBIO make its procedures more open to the Brazilian society, breaking down myths and versions that have arisen, in many cases, because of the closed, untransparent procedures that marked its activities. We know that a forum of scientists cannot become a popular assembly but, also, it must not be characterized by an atmosphere of gods above the claims of the civil society. The authoritarian style that marked the CTNBIO, especially its presidency up until the year 2001, did not effectively contribute to the development of a biosafety policy in the best interests of the whole Brazilian society. (cited in Glover et al. 2003, 9)

The MP ends his report recommending 'the definition of new criteria for the election of the members of CTNBIO and other measures to increase the transparency of its decisions, in order to bring it closer to the civil society'. In relation to the intensity of civil society opposition to GM crop development in Brazil, CTNBio has sought to broaden the range of stakeholders it consults within its decision-making. From 1999 onwards, it sought to conduct 'extensive' consultations in advance with non-biotechnologists in Brazil's National Academy of Science, responding to the criticism that it gives too great a voice to proponents of the technology. Nevertheless, its reputation as an essentially promotional rather than precautionary body has deterred critical civil society groups from getting involved to replace IDEC on the Commission once the group left in protest.

The degree of access and participation of civil society groups is also defined by their relation with the party in power. Activists note the difference in Brazil,

\section{(C) 2008 The Author}

Journal compilation @ 2008 Blackwell Publishing Ltd

Journal of Agrarian Change, Vol. 8 Nos. 2 and 3, April and July 2008, pp. 345-376. 
for example, between the Cardoso administration for whom, in their view, agrarian questions were reduced to questions of police capacity to deal with dissident groups and the Lula administration on the other hand, which has invited MST to participate in cabinet councils dealing with issues such as hunger and agrarian reform. This is in spite of activist critiques about the limited nature of that reform process and the government's continued support for an exportoriented agribusiness model (Santos 2006).

Public discussion on the potential impacts of the GMO being assessed is required in Brazil even if some representatives of the CTNBIO believe that such public involvement is not necessary because biosafety issues are extremely 'technical'. The NGO coalition 'For a Brazil free of GMOs' struggled to make an environmental impact assessment with public involvement mandatory. The strategy has been to open up the 'black box' of decision-making to a plurality of voices and to contest justifications for excluding public inputs, namely that the technical nature of the issues prohibits all but narrowly defined expert participation. What Levidow (1998) refers to as the 'biotechnologizing of democracy' has served to restrict debate to a pre-defined set of scenarios about biotech futures rather than engage broader social and ethical concerns. 'Technical' problems amendable to neo-liberal risk-benefit analysis demand a privileged role for experts. As Newell puts it: 'with biotechnology we see the essential tenets of modernity and capitalism brought to bear to foreclose broader democratic engagements with what amount, in many settings, to key questions of rights, access and entitlements to food and livelihood security' (2006, 76). A common political device employed by state and corporate elites towards this end is to invoke the public as ignorant, ill-informed and only able to engage in issues of science and technology on 'emotional' grounds (Wynne 2001). The effect is that "participation in decisions about GM crops for most publics takes the form of exercising consumer rights to buy, or refuse to buy, a product that has already been approved for market entry despite the efforts of activists to democratize decision-making through attempting to secure public rights to information, to expose approval processes to public scrutiny' (Newell 2006, 77).

In response to the limitations of formal channels of public participation, ActionAid Brazil, FASE (Federacao dos Orgaos para Asistencia Social e Educacional), MST, CUT (Confederation of Labour Unions), and Advisory and Research Centre (ESPLAR) have promoted citizen juries targeting small-scale farmers, landless people and poor urban consumers. The first one took place in Fortaleza, capital of the Northeast state of Ceará, in April 2001. The second was organized in Belem do Para, capital of the Amazonian state of Para, in September 2001. The jury was selected 'randomly' from lists provided by a representative range of community-based associations. Hundreds of small-scale farmers, landless people and poor urban consumers attended the events. Among the questions addressed by the jury was 'is there enough evidence that GMOs do not threaten the environment?' and 'is the process of testing and the commercial use of GMOs democratic, transparent and careful enough?' After hearing evidence from witnesses, the answer to both questions from the jury was 'no', in both 
events. The trial took place over two days. ${ }^{13}$ A representative from ActionAid Brazil concluded that 'these people, always excluded from the process of policymaking in issues that affect them very much, had the opportunity to access all the information and to decide about it via members of the jury' (Campolina 2001, 29). Another citizen jury took place in Rio in August 2002. It followed the same procedures of the previous ones, but instead targeted urban consumers. In 2004 there was a citizen jury in Parana. As Scoones notes, 'this was more a mass rally than a jury process with 3000 MST activists attending' (2005, 36). The timing of the event also ensured political buy-in from state officials, coming as it did at a critical point in the electoral cycle for the governor.

In Argentina, there has been a high level of scepticism about the necessity of a National Biosafety Framework with provisions for public participation. Business groups, in particular, were fearful that such a process would generate doubts and scepticism about the technology where they claim none currently exist. ${ }^{14}$ Within the formal decision-making process, access for NGOs critical of the technology has been difficult. CONABIA is, in many ways, the epicentre of the approval process for agricultural biotechnology applications. It is a multisectoral body, wherein private and public organizations are represented. Membership and coordination have been modified with increasing input from the private sector. Currently, CONABIA is made up of three public research institutions, four public universities, six private sector associations, one civil society (consumers') organization, four SAGPyA (Secretary of Agriculture, Fisheries and Food) representatives and two members of the Health Ministry, though this composition is subject to change over time. The key decisions about who sits on the committee are taken by the Secretary of Agriculture, though members of CONABIA claim that anyone with 'professional experience' can apply to participate. When asked about the absence of consumer or environmental groups, one official claimed to have invited Greenpeace and consumer organizations to participate 'but they have no one to propose with professional capacity in this area'. ${ }^{15}$ This use of science-based criteria for determining participation in decision-making and as a mechanism for deciphering 'legitimate' from nonlegitimate stakeholders is also common to many other regulatory systems, but it undoubtedly serves to entrench a less critical perspective regarding the risks associated with the technology (Newell 2006). A former CONABIA representative from the Secretary of Natural Resources and Sustainable Development, who attempted to raise critical questions about biosafety issues that had not been adequately studied, is reported to have been strongly outnumbered on the body by advocates of the technology. ${ }^{16}$

13 For more on such deliberative policy experiments see Scoones and Thompson (2003) and Pimbert and Wakeford (2002).

${ }_{14}$ Interview, head of ArgenBio, November 2006.

15 Interview, CONABIA, November 2006.

16 Interview, agronomist, November 2006. 
What we observe then is an absence of formal invited spaces that function as arenas for the effective deliberation, let alone contestation, of biotechnology for activists. Given this, attempts to construct alternative venues for articulating 'dissident' voices are unsurprising, though their inability to impact authoritative decision-making will continue to be a serious limitation upon their ability to effect lasting change.

\section{REPRESENTATION}

As the editors of this collection note: 'it is clear that while a few globalized movements have made impressive strides, far more groups of the rural poor are not represented at all, even nominally in these transnational agrarian movements' (Borras et al. 2008). This is true even in countries such as Brazil, 'purported to be strongholds of these movements'. In part, this results from the multiple roles farmers perform simultaneously as producer, activist and local and global citizen. Edelman spells this out concretely: 'the same individuals who mobilize for international conferences may also have to assemble a legal team to defend contested property titles, follow up on orders for a cooperative's rubber boots and harvest a field of cabbages before the rains arrive' (2003, 214). This may be particularly true of 'rural celebrities' such as Bove and Schmeiser in the case of GM. Pressed by constraints of time, priority and lack of understanding of seemingly distant and technical trade policy processes, the possibilities for direct representation are, realistically, few. This inevitably leaves tremendous scope for autonomous agenda-setting by the leadership of broad-based coalitions.

The rise and fall of ASOCODE (Association of Central American Peasant Organizations for Cooperation and Development) provides a cautionary tale for other transnational coalitions seeking to scale up to regional and international arenas while remaining responsive to their social base. As Edelman reflects: 'in ASOCODE's case, a top-heavy organisation, a preponderance of activities that responded to donor rather than peasant priorities and incessant internecine squabbling brought the association to a point where it still exists in name but enjoys little of its earlier support, dynamism or prestige' (2003, 191).

In relation both to 'mass' mobilizations as well as channelling influence through formal institutional channels, issues of who speaks for whom and about what inevitably arise. Such issues can also raise tensions between civil society groups as they attempt to work together and are faced with the question of who is being represented. In coalition-building among trade activists around NAFTA, trade unions raised concerns about the representative base of NGOs who they caricatured as non-governmental individuals, while labour movements were also accused of having hierarchical non-inclusive decision-making structures (Newell and Tussie 2006). When issues of funding and diverse protest cultures in which middle-class students rub shoulders with very poor campesinos are added to the mix, the potential for friction is immense. For example, in mobilizations around NAFTA, questions were asked of those groups working to secure an environmental agreement within the treaty about whether their

\section{(C) 2008 The Author}

Journal compilation (9) 2008 Blackwell Publishing Ltd

Journal of Agrarian Change, Vol. 8 Nos. 2 and 3, April and July 2008, pp. 345-376. 
support for the trade agreement bore any relation to the corporate funding they received from economic interests likely to benefit from the trade provisions.

There is also an interesting set of contradictions that emerge from the adoption of anti-GM stances by movements such as the MST when many of their rank and file members have adopted GM seeds, albeit in most cases illegally. Membership of transnational alliances such as Vía Campesina and participation in fora such as the World Social Forums, often hosted in Porto Alegre and, therefore, providing privileged access for high-profile Brazilian groups such as MST, encourage the leadership to adopt anti-GM stances, which are consistent with overall strategies aimed at challenging the power of agri-business in Brazil and beyond. But rejection of the technology by movement leaders sits uneasily with its widespread adoption by the members of the movement and perhaps points to an absence of internal debate over the movement's position on this particular issue. The personal reflections of one long-standing commentator on rural social movements in Brazil are worth quoting at length:

We simply do not have social struggles against biotechnology in Brazil. At most we have some sporadic 'social reactions' against GMOs. There is a small group of NGOs that keep fighting the conservative prevailing trend on these themes in Brazil but with no social base. Their protests are marginal with no repercussion whatsoever in the media or elsewhere. The MST and Vía Campesina do not have any informed social groups backing the political rhetoric of their leaders when dealing with GMOs or agricultural biotechnology per se. The fact is that when landless families and workers participate in any action sponsored by the movement, they can even carry banners attacking trade and so on, but when you talk to them there is deep ignorance about these issues. These differences suggest that the targets of the leadership are built by a small group and do not find any repercussions with the lower groups within the movement. One of the most bizarre political developments is, for example, the anti-GMO stance of the MST and the plain fact that farmers in rural settlements under the influence of the movement in grain producing areas are all using GMOs in the fields. ${ }^{17}$

Scoones is similarly sceptical about the level of comprehension and political buyin of rural poorer groups to discourses articulated about biotechnology by elite or vanguard rural NGOs or movements. He notes:

Most rural dwellers ... do not really have an idea of what GM crops are and are mobilized on other issues - fears about the unknown (terminator crops, Frankenstein foods etc.), concerns about patents, loss of local varieties and so on. Indeed, very often the very same farmers mobilized by organized farmer movements - whether KRRS in Karnataka or the MST

17 Personal communication, commentator and activist on rural development in Brazil, 12 December 2006.

(C) 2008 The Author

Journal compilation @ 2008 Blackwell Publishing Ltd

Journal of Agrarian Change, Vol. 8 Nos. 2 and 3, April and July 2008, pp. 345-376. 
in Brazil - are the same farmers planting pirated GM crops illegally, or would try them out if they could. $(2005,18)$

Higher levels of direct engagement with those they claim to represent are possible around more central livelihood concerns. Questions of agrarian reform, access to land and the right to food tap into deeply-felt concerns by those whose livelihoods are tied to rural development. It might justifiably be argued that there is no need to consult a membership base of poor and often landless farmers about their desire for land. But 'discourse coalitions' that form around slogans such as 'food sovereignty' disguise the fact that many, even very small producers, are thoroughly dependent on an export-led system of agriculture and though they might benefit from land reform, localized economies divorced from global supply chains may well be disastrous for their existing livelihoods. In this sense Scoones might be right to suggest that biotech, rather than being an issue that bubbled up from below, with rank and file members demanding a strong leadership stance, represented a strategically useful opportunity for a movement like MST to raise its profile and consolidate a position within supportive international networks. He notes: 'as an increasingly internationalized movement - with website and support groups in the US and Europe . . . [and] the arrival of activists by the plane load to Porto Allegre for the WSF festivities each year, the MST were able to raise their international (and so local) profile and forge links with the hall of fame of international anti-GM activism' (2005, 22).

As the editors of this collection note in their introductory text, there is at best only a 'partial representation' at work when claims to speak on the basis of a mass social base are made without corresponding mechanisms within movements for soliciting, let alone acting upon, concerns that may percolate from the bottom up. As the editors note, 'effective representation of the social base's interests within their movements should not be assumed to be automatic or permanent and unproblematic. "Effective representation" is dynamically (re)negotiated within and between leadership and membership sections of movements over time.'

Here we encounter the politics of 'brokerage' performed by intermediaries 'speaking for not with', whose claim to legitimacy is alleged to be their social base. The danger is that maintaining a coalition, particularly when there is the prospect of continued funding, becomes an end in itself. In this context, the rationale of the organization, to serve a particular marginalized constituency, becomes subordinated to the need to sustain the jobs of those in the secretariat, keep up the momentum of a campaign or secure funding for the next international event. This does not leave much time for establishing whether supporters agree that this is a priority for the coalition, even if the means to find this out were clearly established. As Edelman puts it, "network practices of representation - submitting proposals, organizing meetings, publishing newsletters or web sites, drafting "action platforms" - sometimes seek to demonstrate the effectiveness of a network with reference to its own self-description and activities rather than to tangible impacts on targeted constituencies, policies and institutions' 
(2003, 214). Particularly when, as happened with the MST in Brazil, movements are invited to participate in formal invited institutional spaces, participation and, therefore, representation is rarely direct. The dilemmas of representation are intensified by such engagements with what activists often call 'friendly governments ${ }^{18}$ or movements in power. As with MST, frustration with the pace of reform through institutional means and the careful politics of compromise and negotiation that this necessarily implies, can lead to frustrations and an intensification of direct action strategies, for which the movement is notorious (Petras and Veltmeyer 2005).

We have then to view even allegedly 'mass' movements within the broader context of 'disorganized majorities' that are neither mobilized nor transnationalized. There is also the phenomenon of well-organized minorities; vocal groups with good international connections but little in the way of social base or national influence. The Argentine Grupo Reflexion Rural, a small rural development NGO, has managed to cultivate links with groups within the region such as RALLT (Red por una Americá Latina Libre de Transgenicos) and internationally through World Social Forum events. Their rejection of biotech is part of a broader critique of the social and environmental impacts of a model of exportoriented agri-business development, an emphasis that aligns them with antiglobalization activists who have been willing to offer them a platform at activist gatherings in Europe and elsewhere. ${ }^{19}$ Adopting the media-savvy tactics of groups such as Greenpeace, including protests outside corporate conferences and expos on agricultural biotechnology, they present journalists with good photo opportunities, but according to some, do not have the research or positions behind their advocacy. ${ }^{20}$

\section{CONCLUSIONS}

Evaluating the impact and broader significance of these interventions in the politics of trade and agricultural development with respect to biotechnology in Latin America with any degree of precision is a fraught exercise. There are clearly many variables that explain the degree of impact that groups and movements have had. In classic terms, the impact of collective action is affected by 'political opportunity structures', 'resource mobilization' and 'framing' (McAdam et al. 2003). But we have also seen how the micro-politics of mobilization suggest a series of other determining factors which affect the extent to which the agenda of biotech activists makes any advances: the importance of party politics, the role of the media and the differential impact of strategies and protest cultures in diverse political settings.

\footnotetext{
18 This theme emerged as a key theme of discussion in a workshop we organized with trade activists at the 'Cumbre por la integracíon de los Pueblos', a counter summit held in Cochambamba, Bolivia in December 2006 at the same time as the meeting of the Community of South American Nations. 19 For example, Adolfo Boy was invited to speak at the counter-summit to the EU-Latin America trade meeting in Vienna, May 2005.

20 Interview with a journalist, 15 November 2006.
} 
There are also of course varying indicators of that impact. For most, change in formal government or corporate policy is the aim: successful demands for a new regulation or the overhaul of a policy that the movements were opposed to. Examples would include the provision of environmental impact assessments, tougher biosafety provisions, enhanced restrictions on the use of GURTs or declarations from firms that they will not source soya from areas being deforested to make way for the crop's cultivation. For other movements, the goal is raising public awareness about the technology and the way in which trade agreements that governments are signing undermine national autonomy with regard to the governance of the technology. For others still, including the MST and Vía Campesina, campaigns around biotechnology are of secondary importance to the real issues, which are land reform and an economy dependent on powerful agribusiness investors. Achieving change in those arenas given the alliances between state managers and (trans)national capital that sustain this accumulation strategy make struggles over biotechnology seem insignificant by comparison.

Engineering direct and dramatic shifts in policy may be a distant aim, but the short-term challenge is to engage the public in the debate and contest current media and government framings of the issue. The fact that major governments in the region continue to support biotechnology (Argentina, Brazil) or in some cases have had their opposition or scepticism towards it overturned (Peru, Bolivia) is not evidence of movement failure. The strength, economic weight and political resources that proponents of biotechnology and potential beneficiaries of trade liberalization agreements have vastly outweigh those of their opponents. Yet, through careful strategic positioning, extensive networking and alliance building, they have, on occasion, been able to outmanoeuvre their opponents. As Peleaz and Schmidt note in relation to Brazil, for example, for some time "with all its privileged technical and scientific knowledge, its experience in approaching regulators in other countries and with its considerable financial resources to establish a large marketing network and invest in "economic pressure", Monsanto could not get authorization for the release of its RR soybeans' (2004, 254).

Biotech activists have been highly astute at forging connections between biotech and issues which resonate with diverse public audiences, around the impact of the technology upon the rural livelihoods of poorer farmers, around health and environmental concerns for urban consumers. They have, on occasion, been able to challenge the terrain of the debate, introducing alternative forms of expertise and highlighting the importance of cultural values (Fitting 2006). They have successfully constructed informal spaces to enhance citizen participation in policy debate to take it beyond an arena of deliberation among experts. They have also been adept at forging connections with international anti-GM activists who, in turn, exercise influence in multiple arenas. This can create 'boomerang' effects (Keck and Sikkink 1998) where a biotech company in Europe finds itself subject to scrutiny for its actions in rural Brazil, for example.

Nevertheless, despite temporary victories in skirmishes with (largely foreign) capital and the state, the war over biotechnology in the largest countries of the

\section{(C) 2008 The Author}

Journal compilation @ 2008 Blackwell Publishing Ltd

Journal of Agrarian Change, Vol. 8 Nos. 2 and 3, April and July 2008, pp. 345-376. 


\section{Peter Newell}

region has for the time being been won. Through a slow process of attrition, careful coalition-building and concerted lobbying in institutional and public arenas across scales, biotech firms have had their products accepted. What remains undecided is the future of trade liberalization in the region and the extent to which it will be advanced regionally or bilaterally. The challenge for activists, as we have seen, is to ensure that success in challenging regional and hemispheric initiatives does not result in bilateral agreements whose provisions go even further than the proposed contents of the regional treaty (Gallagher, 2008). The case of the FTA between the US and Peru, mentioned above, is a case in point.

Contesting biotechnology in national arenas will continue to be key and here impact has varied significantly across the region. In Argentina, there are very few spaces available to contest the technology. The alignment of material, institutional and discursive power produces an effect of 'agro-hegemony'. The same is true of Uruguay and Paraguay by default. In Brazil, we have witnessed increasing acceptance of the technology despite early and ongoing objections to the promotion of GMOs. When faced with opposition, the state has leant strong backing to agribusiness. Despite the great hopes vested in President Lula by anti-GM activists because of views expressed prior to his election and his ties to oppositional movements, his incoming Minister of Agriculture, Roberto Rodrigues, was quick to lend his support to his allies in the agribusiness sector. Hence in March 2003, when faced with the decision about whether to uphold the GM ban and destroy the crop harvest for 2002-03 or to allow its sale, the government allowed the marketing of the GM crops, much to activists' dismay. A further Presidential decree again allowed the sale of GM soya from the 200304 seasons, despite it still not having been approved for planting (Scoones 2005). The Biosafety Law approved by the Senate in 2005 has paved the way for the consolidation of Brazil's position as a global leader in biotechnology, closely following the path set by neighbouring Argentina.

The country's dependence on agri-business circumscribes the possibilities for and effectiveness of political challenges. As one commentator said to me: "it would be difficult to create political opposition to agri-business or problematize modern agricultural technology at the moment when the financial surplus of Brazilian exports are formed especially from export of grains, mainly produced by agri-business'. ${ }^{21}$ In a further correspondence this informant noted: 'especially if we are thinking in terms of GMOs for agricultural production, it appears the battle has already been won by commercial interests. The reason is not political but practical. GMOs in grain production, especially soybean, are now spread throughout Brazil and I cannot see how to avoid its use anymore. Some state governments are still talking about restrictions and so on, but this is for the public because no real barrier can be imposed'. ${ }^{22}$

\footnotetext{
21 Personal communication, commentator and activist on rural development in Brazil, 12 December 2006.

22 Personal communication, commentator and activist on rural development in Brazil, 12 December 2006.
} 
An article that appeared in the opinion pages of the Folha de Sao Paulo newspaper supports this reasoning, pointing out the scale of illegal planting of crops such as soya and cotton and the virtual impossibility of effectively regulating it, producing an 'institutional paralysis'. ${ }^{23}$ Perhaps the battle for biotech has already been won. We certainly have to be cognizant of the power wielded by those in favour of the technology, supportive of the regional trade integration that ensures its diffusion and protection throughout Latin America, which includes some of the most influential lobbies in the contemporary global political economy from the agribusiness sector. There is a great deal of pressure being brought to bear upon governments throughout the region into accepting agricultural biotechnology. Whether it is through threats of trade retaliation or the forced acceptance of GM food aid as in the case of Bolivia and Ecuador, the use of bilateral trade agreements that synchronize regulatory systems with regard to biotechnology as in the case of the agreement between Peru and the US or the legal action taken by Monsanto against its former ally Argentina, countries in the region operate in a context of 'bounded autonomy' (Newell 2006). Many governments, it seems, believe they cannot afford to debate the future of the technology. The challenge for activists is to demonstrate clearly that they cannot afford not to debate the technology, given its ability to transform systems of agricultural production upon which many of region's poorest people depend.

\section{REFERENCES}

Acción Ecológica, 2004. 'Area de Libre Comercio de las Américas'. http://www. accionecologica.org/index.php?option=com_content\&task=view\&id=165\&Itemid=242, Accessed 2 February 2007.

Andrioli, A.I., 2006. 'Soja Orgânica versus Soja Transgênica'. Movimento Dos Trabalhadores Rurais sem Terra, October 30. http://www.mst.org.br/mst/pagina.php?cd=2334, Accessed 21 February 2007.

Bellisario, A., 2007. 'The Chilean Agrarian Transformation: Agrarian Reform and Capitalist "Partial" Counter-Agrarian Reform, 1964-1980: Part 1: Reformism, Socialism and Free-Market Neoliberalism'. Journal of Agrarian Change, 7 (1): 1-34.

Benbrook, C.M., 2005. 'Rust, Resistance, Run Down Soils and Rising Cost: Problems Facing Soybean Producers in Argentina'. AgBioTech InfoNet, Technical paper no. 8. http://www.earthscape.org/p1/ES16592/Greenpeace_rust.pdf, Accessed 12 October 2006.

Boff, L., n.d. 'Transgênicos? Não'. http://www.cebusai.org.br/transgenicos.htm, Accessed 12 May 2006.

Borras, S. Jr, 2004. 'La Vía Campesina: An Evolving Transnational Movement'. TNI Briefing No. 2004/6. Amsterdam: Transnational Institute.

Borras, S. Jr, M. Edelman and C. Kay, 2008. 'Transnational Agrarian Movements: Editors' Introduction'. Journal of Agrarian Change, 8 (2/3).

Boy, A., 2006. 'Grupo Reflexión Rural'. Presentation, Enzando Alternativas, Vienna, 1013 May 2006.

23 'Barreira transgênica', Folha de Sao Paulo 24/12/06.

(C) 2008 The Author

Journal compilation @ 2008 Blackwell Publishing Ltd

Journal of Agrarian Change, Vol. 8 Nos. 2 and 3, April and July 2008, pp. 345-376. 
Burnham, P., 2002. 'Class Struggle, States and Circuits of Capital'. In Historical Materialism and Globalisation, eds M. Rupert and H. Smith, 113-29. London: Routledge.

Campolina, A., 2001. 'Brazilian Small-Scale Farmers and Poor Consumers Reject GMOs'. LEISA Magazine, 29 December.

Clapp, J., 2006. 'The Political Economy of Food Aid in an Era of Agricultural Biotechnology'. In The International Politics of Genetically Modified Food: Diplomacy, Trade and Law, ed. R. Falkner, 85-101. Basingstoke: Palgrave.

Conway, G., 1999. The Doubly Green Revolution: Food for All in the Twenty-First Century. New York: Cornell University Press.

Edelman, M., 2003. 'Transnational Peasant and Farmer Movements and Networks'. In Global Civil Society, eds H. Anheier, M. Glasius and M. Kaldor, 185-221. Oxford: Oxford University Press.

EDM (En Defensa del Maíz), 2002. Conclusiones del seminario, Ciudad de México, 23 and 24 January. http://www.ceccam.org.mx/ConclusionesDefensa.htm, Accessed 4 December 2007.

Fitting, E., 2006. 'The Political Uses of Culture: Maize Production and the GM Corn Debates in Mexico'. Focaal: European Journal of Anthropology, 48: 17-34.

FoEI (Friends of the Earth International), 2007. Who Benefits from GM Crops? An Analysis of the Global Performance of GM Crops (1996-2006). Amsterdam: Friends of the Earth International.

Gallagher, A., 2008. 'Trading away the Ladder? Trade Politics and Economic Development in The Americas'. New Political Economy, 13 (1): 37-59.

Galli, E., 2005. 'De la Chaucha de Soja al Reactor Nuclear de Investigación'. La Nación, 4 January, 2.

Global Exchange, 2004. 'Top Ten Reasons to Oppose the Free Trade of the Americas'. http://www.globalexchange.org/campaigns/ftaa/topten.html, Accessed 2 August 2004.

Glover, D. and P. Newell, 2004. 'Business and Biotechnology: Regulation of GM Crops and the Politics of Influence'. In Agribusiness and Society: Corporate Responses to Environmentalism, Market Opportunities and Public Regulation, eds K. Jansen and S. Vellema, 200-31. London: Zed Books.

Glover, D., J. Keeley and P. Newell, 2003. Public Participation and the Cartagena Protocol on Biosafety. A Review for DfiD and UNEP-GEF. Brighton: Institute of Development Studies.

Greenpeace, 2006a. 'Desmontes S.A: Quiénes Están Detrás de la Destrucción de los Ultimos Bosques Nativos de la Argentina'. Greenpeace Argentina Report. http:// www.greenpeace.org/raw/content/argentina/bosques/desmontes-s-a.pdf, Accessed 15 October 2006.

Greenpeace, 2006b. 'A Turning Point in the Fight to Protect the Amazon'. The Guardian, 28 September 17.

Hajer, M.A., 1995. The Politics of Environmental Discourse: Ecological Modernization and the Policy Process. Oxford: Oxford University Press.

Hochstetler, K., 2003. 'Fading Green? Environmental Politics in the Mercosur Free Trade Agreement'. Latin American Politics and Society, 45 (4): 1-33.

Icaza, R., 2004. Civil Society and Regionalisation. Exploring the Contours of Mexican Transnational Activism. CSGR Working Paper No. 150/04, Warwick University.

James, C., 2006. Global Status of Commercialized Biotech/GM Crops. ISAAA Briefs No. 35. Ithaca, NY: ISAAA.

Jansen, K. and S. Vellema, eds, 2004. Agribusiness and Society: Corporate Responses to Environmentalism, Market Opportunities and Public Regulation. London: Zed Books.

(C) 2008 The Author

Journal compilation @ 2008 Blackwell Publishing Ltd

Journal of Agrarian Change, Vol. 8 Nos. 2 and 3, April and July 2008, pp. 345-376. 
Kay, C., 2002. 'Chile's Neo-Liberal Agrarian Transformation and the Peasantry'. Journal of Agrarian Change, 2 (4): 464-501.

Keck, M. and K. Sikkink, 1998. Activists Beyond Borders: Advocacy Networks in International Politics. Ithaca, NY: Cornell University Press.

Kenfield, I. and R. Burbach, 2007. 'Landless Rural Worker Shot by Security Company Hired by Multinational Syngenta'. Posted on the 'Brazil Network' list serve, 21 October 2007.

Kossoy, A., 2003. 'Iniciativas de Asociaciones de Productores Agropecuarios: La Incorporación de la Soja en la Emergencia Alimentaria'. In Respeuestas de la Sociedad Civil a la Emergencia Social, eds I. González Bombal, 89-119. Buenos Aires: CEDES.

Levidow, L., 1998. 'Democratizing Technology or Technologizing Democracy? Regulating Agricultural Biotechnology in Europe'. Technology in Society, 20 (2): 211-26.

Lipton, M., 2001. 'Reviving Global Poverty Reduction: What Role for Genetically Modified Plants?'. Journal of International Development, 13 (7): 823-46.

McAdam, D., S. Tarrow and C. Tilly, 2003. 'Dynamics of Contention'. Social Movement Studies, 2 (1): 99-102.

Murray, W., 2006. 'Neo-Feudalism in Latin America? Globalisation, Agribusiness and Land Re-Concentration in Chile'. The Journal of Peasant Studies, 33 (4): 646-77.

Newell, P., 2006. 'Corporate Power and Bounded Autonomy in the Global Politics of Biotechnology'. In The International Politics of Genetically Modified Food, eds R. Falkner, 67-85. Basingstoke: Palgrave.

Newell, P., 2007. 'Trade and Environmental Justice in Latin America'. New Political Economy, 12 (2): 237-59.

Newell, P. and D. Tussie, 2006. 'Civil Society Participation in Trade Policy in Latin America: Lessons and Reflections'. IDS Working Paper, 267. Brighton: Institute for Development Studies.

Oya, C., 2005. 'Sticks and Carrots for Farmers in Developing Countries: Agrarian Neo-Liberalism in Theory and Practice'. In Neo-liberalism: A Critical Reader, eds S. Saad-Filho and D. Johnston, 127-35. London: Pluto Books.

Paarlberg, R., 2001. The Politics of Precaution: Genetically-Modified Crops in Developing Countries. Washington, DC: IFPRI and Baltimore, MD: John Hopkins Press.

PCL (Pastoral Commission on Land), 2004. 'Declaration on GMOs'. http://www. cptnac.com.br/?system=news\&action=read\&id=1230\&eid=88, Accessed 21 August 2006.

PCL (Pastoral Commission on Land), n.d. 'The Solution is to Preserve'. http:// www.cptnac.com.br/?system=news\&eid=87, Accessed 21 August 2006.

Peleaz, V. and W. Schmidt, 2004. 'Social Struggles and the Regulation of Transgenic Crops in Brazil'. In Agribusiness and Society: Corporate Responses to Environmentalism, Market Opportunities and Public Regulation, eds K. Jansen and S. Vellema, 232-61. London: Zed Books.

Pengue, W.A., 2005. Agricultura Industrial y Transnationalización en América Latina: ¿La Transgénesis de un Continente? Mexico City: PNUMA and Buenos Aires: GEPAMA.

Petras, J. and H. Veltmeyer, 2005. Social Movements and State Power. London: Pluto Press. Pimbert, M. and T. Wakeford, 2002. Prajateerpu: A Citizen's Jury/Scenario Workshop on Food and Farming Futures for Andhra Pradesh India. Brighton: Institute for Development Studies and London: International Institute for Environment and Development.

RACDV (Rede Alerta Contra o Deserto Verde), n.d. 'Comunidades e Monocultures de Arvores'. http://www.wrm.org/uy/inicio.html, Accessed 12 April 2006.

Radio Mundo Real, n.d. 'Terminator Seeds are Killer Seeds, of Other Crops and of Peasants'. http://www.viacampesina.org/main_sp, Accessed 12 December 2006.

\section{(C) 2008 The Author}

Journal compilation @ 2008 Blackwell Publishing Ltd

Journal of Agrarian Change, Vol. 8 Nos. 2 and 3, April and July 2008, pp. 345-376. 
RALLT (Red por una Americá Latina Libre de Transgenicos), 2007. 'Una Red de Resistencia a los Organismos Transgénicos en América Latina’. http:// www.rallt.org.menus/mision.htm, Accessed 12 September 2007.

Santos, I.F., n.d. 'Action Day Against Terminator Mobilizes Vía Campesina and Environmentalists'. http://www.viacampesina.org/main_sp, Accessed 30 March 2006.

Santos, M., 2006. 'Inimigo é Parceria Entre Latifúndio, Agronegócio e Empresas Transnacionais'. Movimento Dos Trabalhadores Rurais sem Terra, 13 December. http:// www.mst.org.br/mst/pagina.php?cd=2593, Accessed 9 February 2007.

Scoones, I., 2005. 'Contentious Politics, Contentious Knowledges: Mobilising Against GM Crops in India, South Africa and Brazil'. IDS Working Paper, 256. Brighton: Institute for Development Studies.

Scoones, I. and J. Thompson, eds, 2003. 'Participatory Processes for Policy Change: Learning from Experiments in Deliberative Democracy'. PLA Notes 4.

Stedile, J.P., 2004. 'Who Does the Agribusiness Model of Agriculture Serve?' Movimento Dos Trabalhadores Rurais sem Terra, 1 June. http://www.mst.org.br/mst/ pagina.php?cd=500, Accessed 6 March 2007.

Tarrow, S., 2005. The New Transnational Activism. New York: Cambridge University Press.

Teubal, M. and J. Rodríguez, 2002. Agro y Alimentos en la Globalizacíon: Una Perspectiva Crítica. Buenos Aires: La Colmena.

The Economist, 2006. 'Argentina's Government and its Farmers'. 26 October. http:// www.economist.com/displayStory.cfm?Story_ID=E1_RDRGRTJ, Accessed 2 November 2006.

Third World Network, 2006. 'US FTA Likely to Open Peru to GMOs?'. 2 October. Kuala Lumpur, Malaysia: TWN Biosafety Information Service.

Thrupp, L.A., 1996. 'New Harvests, Old Problems: The Challenges Facing Latin America's Agro-Export Boom'. In Green Guerrillas: Environmental Conflicts and Initiatives in Latin America and the Caribbean, ed. H. Collinson, 122-32. London: Latin America Bureau.

Vara, A.M., 2005. 'Argentina, GM Nation; Chances and Choices in Uncertain Times'. NYU Project on International GMO Regulatory Conflicts. (http://www.law.nyu.edu/ centers/etc/profrans/Argentina\%20Country\%20Case\%20 Sept\%20\%202005>vara.doc'), Accessed 10 October 2005.

Vía Campesina, 2007. 'Attack by Syngenta's Armed Militia Results in Deaths and Wounded in Brazil'. Press Release, 21 October.

Vía Campesina, n.d. a. 'Open Letter from Vía Campesina to President Lula'. http:// www.viacampesina.org/main_sp, Accessed 12 January 2007.

Vía Campesina, n.d. b. 'Vía Campesina Brazil and the Question of Seeds'. http:// www.cptnac.om.br/?system=news\&action=read\&id=1226\&eid=87, Accessed 20 December 2006.

Vía Campesina, n.d. c. 'Victory of Peasants in Defense of Seeds and Against the Terminator'. http://www.mmcbrasil.comb.br/noticias/080306/060406_via_campe.htm, Accessed 12 April 2006.

Warwick, H., 2000. 'Sygenta: Switching off Farmers' Rights?' Report by Genewatch Action Aid, The Berne Declaration and the Swedish Society for Nature Conservation.

WRM (World Rainforest Movement), 2006. 'Petition to the CBD to Ban the Releast of GM Trees'. http://www.wrm.org.uy/temas/AGM/cartaCBD.html, Accessed 2 April 2006.

Wynne, B., 2001. 'Creating Public Alienation: Expert Cultures of Risk and Ethics on GMOs'. Science as Culture, 10 (4): 445-81. 